\title{
ANALISIS DATA ANTRIAN DI PUSKESMAS PARIT HAJI HUSEIN 2 KOTA PONTIANAK
}

\author{
Pranata Anggi, Yundari, Hendra Perdana
}

\begin{abstract}
INTISARI
Puskesmas adalah salah satu pusat pelayanan kesehatan yang berguna membantu masyarakat dalam membangun kehidupan yang lebih sehat. Permasalahan yang sering terjadi pada puskesmas adalah lamanya prosedur di beberapa fasilitas pelayanan. Hal ini dapat diamati dari kedatangan pasien ke bagian pendaftaran, lalu pasien yang datang ke dokter, dan pasien mengambil obat di bagian instalasi farmasi. Sehingga diperlukan model sistem antrian yang sesuai dengan kondisi fasilitas pelayanan puskesmas. Tujuan penelitian adalah menganalisis proses kedatangan dan waktu pelayanan serta menganalisis model antrian yang sesuai di Puskesmas Parit Haji Husein 2 Kota Pontianak. Penelitian dilakukan dengan tahap yaitu pengumpulan data, analisis data, dan penarikan kesimpulan. Analisis data yang dilakukan untuk distribusi kedatangan dan waktu pelayanan pasien diuji dengan goodness of fit. Dari hasil analisis diperoleh model antrian bagian pendaftaran, poli anak, dan instalasi farmasi adalah $(M / G / 1):(F C F S / \infty / \infty)$. Pada bagian poli umum model antrian yang diperoleh adalah $(M / G / 2):(F C F S / \infty / \infty)$. Kesimpulan yang diperoleh berdasarkan kinerja antrian Puskesmas Parit Haji Husein 2 Kota Pontianak pelayanan pasien dibeberapa fasilitas pelayanan sudah berjalan baik. Dengan rata-rata jumlah kedatangan pasien $(\lambda)$ tidak melebihi rata-rata kecepatan pelayanan pasien $(\mu)$.
\end{abstract}

Kata Kunci: kolmogorov-smirnov, proses poisson, waktu antar kedatangan.

\section{PENDAHULUAN}

Salah satu masalah yang sering dijumpai oleh suatu puskesmas adalah masalah antrian. Masalah antrian merupakan hal yang tidak terlepas dari sebuah sistem pelayanan. Hal ini terjadi karena jumlah fasilitas pelayanan yang tersedia tidak sebanding dengan jumlah pelanggan yang datang sehingga pelayanan tertunda dan selanjutnya menyebabkan proses menunggu dan menimbulkan antrian. Antrian yang terlalu panjang mengakibatkan pelanggan meninggalkan antrian. Dalam teori antrian, hal ini disebut istilah balking[1].

Kehilangan pelanggan tentunya tidak diinginkan oleh penyedia barang dan jasa, tetapi memenuhi keinginan pelanggan mengantri sesingkat mungkin atau bahkan tidak sering mengakibatkan penambahan biaya operasional. Oleh karena itu model antrian dapat membantu pihak puskemas untuk membuat keputusan dengan cara menganalisis antrian. Dari hasil analisis antrian diperoleh banyaknya ukuran kinerja sistem antrian, seperti rata-rata waktu yang dihabiskan oleh pelanggan dalam antrian, rata-rata panjang antrian, waktu yang dihabiskan pelanggan dalam sistem, peluang fasilitas pelayanan kosong, faktor utilisasi sistem serta peluang sejumlah pelanggan berada dalam sistem[2].

Puskesmas Parit Haji Husein 2 Kota Pontianak merupakan penyelenggaraan pembangunan kesehatan perorangan dan upaya kesehatan masyarakat yang ada di Kota Pontianak. Permasalahan yang sering terjadi pada pelayanan pasien adalah lamanya prosedur dibeberapa fasilitas pelayanan seperti bagian pendaftaran, poli umum, poli anak, dan instalasi farmasi. Untuk mengatasi permasalahan tersebut maka dilakukan analisis sistem antrian dengan menerapkan teori antrian pada sistem tersebut. Bentuk sistem antrian dan ukuran kinerja antrian mampu menggambarkan kondisi sistem pelayanan secara tepat.

Dalam penulisan ini batasan masalah yang diambil adalah bagian pendaftaran, poli umum, poli anak, dan instalasi farmasi di Pusksemas Parit Haji Husein 2 Kota Pontianak. Disiplin pelayanan yang digunakan adalah First Come First Serve (FCFS) yaitu pasien yang pertama datang yang pertama dilayani. Pengambilan data dilakukan selama empat hari selama tiga jam setiap harinya dengan asumsi bahwa data tersebut sudah mewakili hari-hari lainnya.

Metode yang digunakan dalam penelitian ini meliputi beberapa tahap yaitu pengumpulan data, analisis data dan penarikan kesimpulan. Metode dalam pengumpulan data adalah pengamatan langsung pada sistem antrian. Setelah data diperoleh, dimulai dari menguji kecocokan distribusi jumlah kedatangan dan waktu pelayanan. Selanjutnya melakukan perhitungan kinerja sistem antrian 
dengan rumus-rumus yang sesuai dengan model sistem antrian. Hal ini untuk mengetahui hasil dari kinerja antrian pada pelayanan pasien Puskesmas Parit Haji Husein 2 Kota Pontianak.

\section{TEORI ANTRIAN}

Teori antrian dikenalkan pada tahun 1909 oleh ahli matematika dan insinyur berkebangsaan Denmark yang bernama A.K. Erlang[3]. Antrian adalah garis-garis tunggu dari pelanggan yang memerlukan layanan dari satu atau lebih pelayanan (fasilitas pelayanan). Proses antrian adalah suatu proses yang berhubungan dengan kedatangan seorang pelanggan pada suatu fasilitas pelayanan, kemudian menunggu dalam satu baris (antrian), dan akhirnya meninggalkan fasilitas pelayanan tersebut setelah dilayani[4]. Sistem antrian adalah suatu himpunan pelanggan, pelayan, dan suatu aturan yang mengatur pelayanan kepada pelanggan.

Tujuan dasar model-model antrian adalah untuk meminimumkan total biaya, yaitu biaya langsung penyediaan fasilitas pelayanan dan biaya tidak langsung yang timbul karena para individu harus menunggu untuk dilayani. Bila suatu sistem mempunyai fasilitas pelayanan lebih dari jumlah optimal, ini berarti membutuhkan investasi modal yang berlebihan, tetapi bila jumlahnya kurang dari optimal maka hasilnya adalah tertundanya pelayanan. Model antrian merupakan peralatan penting untuk sistem pengelolaan yang menguntungkan dengan menghilangkan antrian[3].

Komponen dasar dari proses antrian adalah:

1. Kedatangan

Setiap masalah antrian melibatkan kedatangan, misalnya orang, mobil, atau panggilan telepon untuk dilayani. Proses kedatangan dapat diketahui secara pasti atau berupa suatu variabel acak yang distribusi peluangnya dianggap telah diketahui. Karateristik dan populasi yang dilayani dapat dilihat menurut ukurannya, proses kedatangan, serta perilaku dari populasi yang dilayani. Menurut ukurannya, populasi yang dilayani bisa terbatas (limited) dan tidak terbatas (unlimited).

2. Pelayanan

Pelayanan dapat terdiri dari satu atau lebih dalam satu atau lebih fasilitas pelayanan. Contoh kasir sebuah minimarket dapat terdiri dari satu pelayan dalam satu fasilitas pelayanan. Dalam mekanisme pelayanan ada tiga aspek yang harus diperhatikan yaitu tersedianya pelayanan, kapasitas pelayanan, dan lama pelayanan.

\section{Antrian}

Antrian timbul tergantung dari proses kedatangan dan waktu pelayanan. Jika tidak ada antrian berarti terdapat pelayan yang menganggur atau kelebihan fasilitas pelayanan. Tambahan fasilitas pelayanan dapat diberikan untuk mengurangi antrian atau untuk mencegahnya antrian. Dengan penambahan pelayanan akan menimbulkan pengurangan keuntungan. Sebaliknya, sering timbulnya antrian yang panjang akan mengakibatkan hilangnya pelanggan.

Pada pengelompokan model antrian yang berbeda-beda akan digunakan suatu notasi yang disebut Notasi Kendall. Notasi ini sering digunakan karena notasi tersebut merupakan alat yang efisien untuk mengidentifikasi tidak hanya model antrian, tetapi juga asumsi-asumsi yang harus dipenuhi.

Format umum model adalah sebagai berikut[5]:

dengan,

$$
(a / b / c):(d / e / f)
$$

$a=$ distribusi kedatangan.

$b=$ distribusi waktu pelayanan.

$c=$ jumlah saluran pelayanan pararel dalam sistem.

$d=$ disiplin pelayanan .

$e=$ jumlah maksimum pelanggan yang akan berada dalam sistem (antri dan dilayani).

$f=$ besarnya populasi kedatangan.

Keterangan:

1. Untuk $a$ dan $b$ dapat digunakan kode-kode berikut sebagai pengganti:

$M=$ banyaknya kedatangan berdistribusi Poisson atau pelayanan berdistribusi

Eksponensial, juga sama dengan distribusi waktu antar kedatangan Eksponensial

atau distribusi satuan yang dilayani Poisson.

$D=$ waktu antar kedatangan dan waktu pelayanan adalah konstan.

$G=$ waktu pelayanan berdistribusi umum (General). 
Analisis Data Antrian di Puskesmas.....

$E k=$ waktu antar kedatangan dan waktu pelayanan berdistribusi Erlang atau gamma.

2. Untuk $c$ digunakan bilangan bulat positif yang menyatakan jumlah pelayanan pararel.

3. Untuk $d$ digunakan kode-kode pengganti:

a. First In First Out (FIFO) atau First Come First Served (FCFS).

b. General Service Disciplint (GD).

c. Last In First Out (LIFO) atau Last Come First Served (LCFS).

d. Service In Random Order (SIRO).

4. Untuk $e \operatorname{dan} f$ digunakan kode $N$ (untuk menyatakan jumlah terbatas) atau $\infty$ (tak terhingga satuan-satuan dalam sistem antrian dan populasi kedatangan).

\section{UJI KECOCOKAN DISTRIBUSI}

Uji kecocokan distribusi dari distribusi empirik terhadap distribusi teoritis dilakukan dengan uji Kolmogorov-Smirnov. Uji satu sampel Kolmogorov-Smirnov merupakan suatu uji Goodness of Fit artinya yang diperhatikan adalah tingkat kesesuaian antara distribusi sampel hasil observasi dengan suatu distribusi teoritis tertentu. Uji Kolmogorov-Smirnov dipilih untuk pengujian karena dapat digunakan pada sampel yang kecil dan tidak menghilangkan informasi meski sampel digabungkan dalam beberapa kategori[6].

Adapun langkah-langkah uji Kolmogorov-Smirnov sebagai berikut[7]:

1. Menentukan hipotesis

Hipotesis tentang distribusi kedatangan adalah sebagai berikut:

$\mathrm{H}_{0}$ : kedatangan pasien berdistribusi Poisson.

$\mathrm{H}_{1}$ : kedatangan pasien tidak berdistribusi Poisson.

Jika tidak berdistribusi Poisson, maka kedatangan diasumsikan berdistribusi umum (General).

Hipotesis tentang distribusi waktu pelayanan adalah sebagai berikut:

$\mathrm{H}_{0}$ : waktu pelayanan pasien berdistribusi Eksponensial.

$\mathrm{H}_{1}$ : waktu pelayanan pasien tidak berdistribusi Eksponensial.

Jika tidak berdistribusi Eksponensial, maka waktu pelayanan diasumsikan berdistribusi umum (General).

2. Menentukan taraf signifikansi

Taraf signifikansi $\alpha=5 \%$

3. Statistik uji

dengan,

$$
\mathrm{D}=\max \left|s(x)-F_{0}(x)\right|
$$

D : Difference Absolut

$s(x)$ : Distribusi kumulatif data sampel (data jumlah kedatangan dandata waktu pelayanan).

$F_{0}(x)$ : Distribusi kumulatif dari distribusi yang dihipotesiskan (untuk kedatangan pasien menggunakan distribusi Poisson, sedangkan untuk waktu pelayanan pasien menggunakan distribusi Eksponensial).

4. Kriteria uji

Tolak $\mathrm{H}_{0}$ jika nilai $\mathrm{D}>\mathrm{D}^{*}(\alpha)$. Nilai $\mathrm{D}^{*}(\alpha)$ adalah nilai kritis yang diperoleh dari tabel Kolmogorov-Smirnov.

\section{MODEL ANTRIAN (M/G/1):(FCFS/ $/ \infty)$}

Model antrian (M/G/1):(FCFS/ $/ \infty)$ merupakan model antrian dengan banyak kedatangan berdistribusi Poisson atau waktu antar kedatangan berdistribusi Eksponensial. Pada model ini waktu pelayanan dijabarkan dengan sebuah distribusi umum dengan mean $E(t)$ dan varians $\operatorname{Var}(t)$. Analisis ini sedikit dibatasi dalam arti bahwa analisis ini tidak memberikan hasil analitis yang dapat ditelusuri untuk probabilitas $P_{n}$. Sebaliknya, hasil dari model ini hanya memberikan ukuran-ukuran dasar dari kinerja, termasuk $L_{s}, L_{q}, W_{s}$, dan $W_{q}[8]$.

Formula Pollazck-Khintchine (P-K) digunakan untuk menguraikan sistem antrian ini. Formula ini diuraikan melalui pelayanan tunggal dengan situasi yang didasarkan tiga asumsi berikut (Ari Heryana, 2014)[8]: 
1. Distribusi kedatangan mengikuti proses Poisson dengan tingkat rata-rata $\lambda$ per unit waktu sebelum memasuki fasilitas pelayanan.

2. Distribusi waktu pelayanan yang umum dengan ekspetasi rata-rata pelayanan $E[t]=\frac{1}{\mu}, E\left[t^{2}\right]=\frac{2}{\mu^{2}}$ dan $\operatorname{var}[t]=\frac{1}{\mu^{2}}$

3. Kondisi steady state dinyatakan dengan $\rho=\lambda E(t)<1$.

Nilai rata-rata pelanggan dalam sistem antrian

$$
L_{s}=E(n)=\lambda E(t)+\frac{\lambda^{2}\left[E^{2}(t)+\operatorname{var}(t)\right]}{2(1-\lambda E(t))}
$$

Nilai rata-rata waktu tunggu pelanggan dalam sistem

$$
W_{s}=\frac{L_{s}}{\lambda}
$$

Nilai rata-rata jumlah pelanggan dalam antrian

$$
L_{q}=L_{s}-\lambda E(t)
$$

Nilai rata-rata waktu tunggu pelanggan dalam antrian

$$
W_{q}=\frac{L_{q}}{\lambda}
$$

\section{MODEL ANTRIAN (M/G/C):(FCFS/ $/ \infty)$}

Model antrian (M/G/c):(FCFS/ $/ \infty / \infty)$ adalah model antrian dengan pelayanan ganda, distribusi kedatangan Poisson dan distribusi pelayanan umum.

Nilai rata-rata waktu tunggu pelanggan didalam antrian $W_{q}$, dapat dicari dengan [8]

$$
W_{q}=\frac{\lambda^{c} E\left[t^{2}\right](E[t])^{c-1}}{2(c-1) !(c-\lambda E[t])^{2}\left[\sum_{n=0}^{c-1} \frac{(\lambda E[t])^{n}}{n !}+\frac{(\lambda E[t])^{c}}{(c-1) !(c-\lambda E[t])}\right]}
$$

Nilai rata-rata jumlah pelanggan dalam antrian, $L_{q}$, diperoleh

$$
L_{q}=\frac{W_{q}}{\lambda}
$$

Nilai rata-rata jumlah pelanggan dalam sistem, $L_{S}$, diperoleh

$$
L_{s}=L_{q}+\lambda E(t)
$$

Nilai rata-rata waktu tunggu pelanggan dalam sistem, $W_{S}$, diperoleh

$$
W_{s}=\frac{L_{s}}{\lambda}
$$

\section{HASIL DAN PEMBAHASAN}

Sistem antrian yang diamati pada beberapa fasilitas pelayanan Puskesmas Parit Haji Husein 2 Kota Pontianak adalah Bagian Pendaftaran, Poli Umum, Poli Anak, dan Instalasi Farmasi. Pada bagian pendaftaran Puskesmas, pasien yang datang langsung menuju loket pendaftaran. Di bagian ini, pasien melakukan pendaftaran jika ingin berobat atau sekedar ingin melakukan medical check up ke salah satu dokter. Jumlah pelayan atau petugas yang selalu ada setiap harinya yang melayani pasien ada 1 pelayan.

Pada bagian poli umum, pasien yang datang lalu menunggu dipanggil oleh asisten dokter. Saat di poli umum, pasien dihadapkan pada situasi langsung dilayani atau menunggu giliran untuk dilayani. Jika pasien harus menunggu untuk dilayani, maka pasien harus membentuk antrian dan akan berada dalam antrian hingga pasien mendapat giliran untuk dilayani. Pada bagian poli umum waktu pelayanan dihitung ketika pasien mendapatkan pelayanan dokter hingga meninggalkan ruangan dokter. Jumlah pelayan atau petugas yang melayani pada bagian poli umum adalah 2 dokter.

Pada bagian poli anak, pasien yang datang dihadapkan pada situasi langsung dilayani atau menunggu giliran untuk dilayani. Jika pasien harus menunggu untuk dilayani, maka pasien harus 
Analisis Data Antrian di Puskesmas.....

membentuk antrian hingga pasien mendapat giliran untuk dilayani. Jumlah pelayan atau petugas pada bagian poli anak adalah 1 dokter.

Pada bagian instalasi farmasi puskesmas, pasien yang datang untuk mengambil obat juga dihadapkan pada situasi langsung dilayani atau menunggu giliran untuk dilayani. Jika pasien harus menunggu untuk dilayani, maka pasien harus membentuk antrian hingga pasien mendapat giliran untuk dilayani. Pada bagian instalasi farmasi, jumlah pelayan yang tersedia adalah 1 pelayan.

\section{Uji Distribusi Jumlah Kedatangan}

Pengujian jumlah kedatangan pasien menggunakan uji distribusi dengan Kolmogorov-Smirnov bertujuan mengetahui jumlah kedatangan pasien berdistribusi Poisson atau berdistribusi umum pada beberapa fasilitas pelayanan di Puskesmas Parit Haji Husein 2 Kota Pontianak. Nilai D yang diperoleh pada bagian pendaftaran 0,320 , bagian poli umum 0,309 , bagian poli anak 0,374 , dan bagian instalasi farmasi 0,296 serta nilai $\mathrm{D}^{*}(\alpha)$ yaitu 0,375 . Dapat disimpulkan bahwa jumlah kedatangan pasien berdistribusi Poisson.

\section{Uji Distribusi Waktu Pelayanan}

Hasil pengujian waktu pelayanan pasien menggunakan uji distribusi dengan Kolmogorov-Smirnov bertujuan mengetahui waktu pelayanan pasien berdistribusi Eksponensial atau berdistribusi umum pada beberapa fasilitas pelayanan di Puskesmas Parit Haji Husein 2 Kota Pontianak. Nilai D yang diperoleh pada bagian pendaftaran 1,910, bagian poli umum 1,974, bagian poli anak 1,739, dan bagian instalasi farmasi 1,696 serta nilai $\mathrm{D}^{*}(\alpha)$ yaitu 0,375 . Dapat disimpulkan bahwa waktu pelayanan pasien berdistribusi umum.

\section{Model Sistem Antrian}

Setelah dilakukan uji kecocokan distribusi maka dapat ditentukan model antriannya untuk bagian pendaftaran, poli anak, dan instalasi farmasi model antriannya yaitu (M/G/1):(FCFS/ $/ \infty)$ ). Dengan jumlah kedatangan mengikuti distribusi Poisson (M) dan waktu pelayanan berdistribusi Umum (G) serta jumlah pelayan yang melayani sebanyak 1 orang (c). Disiplin pelayanan adalah yang pertama datang yang pertama dilayani $(F C F S$ ) dan banyak pelanggan yang diizinkan dalam sistem antrian adalah tidak terbatas $(\infty)$ serta populasi kedatangan tidak terbatas $(\infty)$. pada bagian poli umum yaitu $(\mathrm{M} / \mathrm{G} / 2):(F C F S / \infty / \infty)$ jumlah kedatangan mengikuti distribusi Poisson $(\mathrm{M})$ dan waktu pelayanan berdistribusi Umum $(\mathrm{G})$ serta jumlah pelayan yang melayani sebanyak 2 orang (c). Disiplin pelayanan adalah yang pertama datang yang pertama dilayani $(F C F S)$ dan banyak pelanggan yang diizinkan dalam sistem antrian adalah tidak terbatas $(\infty)$ serta populasi kedatangan tidak terbatas $(\infty)$.

\section{Ukuran Kinerja Sistem Antrian}

Hasil analisis ukuran kinerja sistem antrian pada beberapa fasilitas pelayanan di Puskesmas Parit Haji Husein 2 kota Pontianak ditunjukkan pada Tabel 1

Tabel 1 Hasil analisis

\begin{tabular}{crrrrrrrrr}
\hline Bagian & \multicolumn{1}{c}{$\boldsymbol{\lambda}$} & $\bar{X}$ & \multicolumn{1}{c}{$\boldsymbol{\mu}$} & $\mathbf{C}$ & $\boldsymbol{\rho}$ & $\boldsymbol{L}_{\boldsymbol{q}}$ & $\boldsymbol{L}_{\boldsymbol{s}}$ & $\boldsymbol{W}_{\boldsymbol{s}}$ & $\boldsymbol{W}_{\boldsymbol{q}}$ \\
\hline Pendaftaran & 12,17 & 2,91 & 20,63 & 1 & 0,59 & 0,90 & 1,49 & 7,32 & 4,44 \\
Poli Umum & 7,08 & 12,83 & 4,77 & 2 & 0,76 & 0,03 & 1,54 & 13,02 & 10,38 \\
Poli Anak & 5,08 & 5,98 & 10,03 & 1 & 0,51 & 0,50 & 5,08 & 11,88 & 5,88 \\
Instalasi Farmasi & 12,17 & 3,84 & 15,64 & 1 & 0,78 & 2,61 & 3,45 & 16,98 & 13,14 \\
\hline
\end{tabular}


Berdasarkan Tabel 1, diperoleh informasi bahwa pada bagian pendaftaran memiliki rata-rata lama pelayanan 2,91 menit untuk satu pasien dengan jumlah kedatangan pasien sebanyak 12,17 $\approx 13$ pasien. Kemudian dalam 1 jam bagian pendaftaran dapat melayani sebanyak 20,63 $\approx 21$ pasien, dengan tingkat kesibukan sistem (59\%). Rata-rata pasien dalam antrian adalah $0,9 \approx 1$ pasien, dan rata-rata pasien dalam sistem adalah $1,49 \approx 2$ pasien. Rata-rata lama pasien dalam system pendaftaran adalah 7,32 menit dengan rata-rata lama menunggu sebesar 4,44 menit.

\section{PENUTUP}

Dari hasil penelitian dan analisis data yang telah dilakukan maka dapat disimpulkan beberapa hal sebagai berikut:

1. Model antrian yang terjadi dibeberapa fasilitas pelayanan di Puskesmas Parit Haji Husein 2 adalah
a. Model antrian pada bagian pendaftaran adalah (M/G/1):(FCFS/ $/ \infty)$

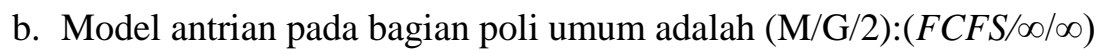
c. Model antrian pada bagian poli anak adalah (M/G/1):(FCFS/ $/ \infty)$

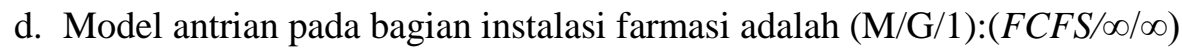

2. Berdasarkan perhitungan kinerja sistem antrian dan analisis secara keseluruhan dapat disimpulkan bahwa sistem di beberapa fasilitas pelayanan di Puskesmas Parit Haji Husein 2 sudah berjalan dengan baik dengan rata-rata jumlah kedatangan pasien $(\lambda)$ tidak melebihi rata-rata kecepatan pelayanan pasien $(\mu)$.

\section{DAFTAR PUSTAKA}

[1]. Andriati, D. Analisis Antrian Pada Bank Mandiri Cabang Fatmawati PI. Jakarta: Universitas Gunadarma. 2003.

[2]. Heizer, J dan Render, B. Manajemen Operasi Buku 2. Jakarta: Salemba Empat. 2005.

[3]. Subagyo, P, Asri, M, dan Handoko T.H. Dasar-Dasar Operation Research. BPFE: Yogyakarta. 2000.

[4]. Taha, H. A. Riset Operasi Jilid Dua. Jakarta: Erlangga. 1997.

[5]. Mulyono, S. Riset Operasi. Jakarta: Fakultas Ekonomi Universitas Indonesia. 2004.

[6]. Siegel, S. Nonparametric Statistics for the Behavioral Sciences. New York: Mc Graw-Hill Company Inc. 1956.

[7]. Daniel, W. Statistik Nonparametrik Terapan. Jakarta: Gramedia. 1989.

[8]. Ross, S. M. Stochastic Processes. New York: John Wiley \& Sons. 1983.

PRANATA ANGGI : Jurusan Matematika FMIPA UNTAN, Pontianak pranata.anggi@student.untan.ac.id

YUNDARI : Jurusan Matematika FMIPA UNTAN, Pontianak yundari@math.untan.ac.id

HENDRA PERDANA : Jurusan Matematika FMIPA UNTAN, Pontianak hendra.perdana@math.untan.ac.id 